\title{
KARAKTERISTIK PENDERITA STROKE ISKEMIK YANG DI RAWAT INAP DI RSUP PROF. DR. R. D. KANDOU MANADO TAHUN 2012-2013
}

\author{
${ }^{1}$ Heidy Patricia \\ ${ }^{2}$ Mieke A. H. N. Kembuan \\ ${ }^{2}$ Melke J. Tumboimbela
}

\author{
${ }^{1}$ Kandidat Skripsi Fakultas Kedokteran Universitas Sam Ratulangi Manado \\ ${ }^{2}$ Bagian Neurologi Fakultas Kedokteran Universitas Sam Ratulangi Manado \\ Email: patriciaheidy@yahoo.com
}

\begin{abstract}
Stroke is rapidly developing clinical signs of focal or global disturbance of cerebral function, with symptoms lasting 24 hours or longer or leading to death, with no apparent cause other than of vascular origin. This study aimed to know characteristic of ischemic stroke patients hospitalized at Prof.Dr.R.D.Kandou hospital in 2012-2013. This research is descriptive retrospective research using secondary data, including the ischemic stroke patient's medical record. The results showed the highest percentage ischemic stroke patients at 45-54 year age group (36\%), male (52\%), high school education (52\%), who work as housewifes (40\%). The highest of modifiable risk factors are hypertension $(74,70 \%)$, followed by increases in total cholesterol $(41,30 \%)$, who had Diabetes mellitus $(17,30 \%)$, who had sodium imbalance (12\%), who had potassium imbalance (16\%), who had chloride imbalance $(18,70 \%)$, alcoholic (28\%), and smoking history (44\%). Based on the results of this research concluded that the most risk factor is hypertension
\end{abstract}

Keywords: ischemic stroke, characteristic, risk factors

\begin{abstract}
Abstrak: Stroke adalah manifestasi klinik dari gangguan fungsi serebral, baik fokal maupun global, yang berlangsung dengan cepat, berlangsung lebih dari 24 jam, atau berakhir dengan kematian, tanpa ditemukannya penyebab selain daripada gangguan vaskular. Penelitian ini bertujuan untuk mengetahui karakteristik penderita stroke iskemik yang di rawat inap di RSUP Prof.Dr.R.D.Kandou Manado tahun 2012-2013. Metode yang digunakan bersifat deskriptif retrospektif yaitu dengan mengambil data sekunder penderita stroke iskemik tahun 2012-2013 di bagian rekam medik RSUP Prof.Dr.R.D.Kandou Manado. Hasil penelitian menunjukan bahwa persentase terbanyak pasien stroke berumur 45-54 tahun (36\%), jenis kelamin laki-laki (52\%), pendidikan terakhir SMA (52\%), yang bekerja sebagai ibu rumah tangga (40\%). Faktor risiko yang dapat diubah tertinggi adalah hipertensi (74,70\%), diikuti oleh kolesterol total meningkat $(41,30 \%)$, yang memiliki penyakit diabetes melitus $(17,3 \%)$, yang memiliki ketidakseimbangan natrium (12\%), ketidakseimbangan kalium (16\%), ketidakseimbangan klorida (18,70\%), yang memiliki riwayat mengkonsumsi alkohol (28\%), dan merokok (44\%). Berdasarkan hasil penilitian ini disimpulkan bahwa faktor risiko terbanyak yang ditemui adalah hipertensi.
\end{abstract}

Kata kunci: stroke, karakteristik, faktor risiko

Berdasarkan definisi WHO ( World Health Organization) stroke adalah manifestasi klinik dari gangguan fungsi serebral, baik fokal maupun global, yang berlangsung dengan cepat, berlangsung lebih dari 24 jam, atau berakhir dengan kematian, tanpa ditemukannya penyebab selain daripada gangguan vaskular . ${ }^{1}$ 
Di dunia, 15 juta orang menderita stroke setiap tahunnya; sepertiga meninggal dan sisanya cacat permanen. ${ }^{2}$ Lebih dari 795,000 orang di Amerika, menderita stroke dan membunuh hampir 130.000 penduduk Amerika per tahunnya. ${ }^{3}$ Pada tahun 2010 stroke merupakan penyakit penyebab kematian ke empat di UK setelah kanker, penyakit jantung, dan gangguan pernapasan, dan menyebabkan hampir 50.000 kematian. $^{4}$

Berdasarkan Riset Kesehatan Dasar Kementerian Kesehatan di tahun 2013 menunjukan telah terjadi peningkatan prevalensi stroke di Indonesia. Dari 8,3 per 1000 penduduk (per mil) pada 2007 menjadi 12,1 per 1000 penduduk pada tahun 2013. Prevalensi penyakit stroke tertinggi terjadi di Sulawesi Utara (10,8 per mil), Yogyakarta (10,3 per mil), Bangka Belitung (9,7 per mil), dan DKI Jakarta (9,7 per mil). ${ }^{5}$

Stroke dibagi menjadi menjadi dua yaitu iskemik dan hemoragik, yang seringkali diawali oleh adanya lesi atau perlukaan pada pembuluh darah arteri. Dari seluruh kejadian stroke, duapertiganya adalah iskemik dan sepertiganya adalah hemoragik. Disebut stroke iskemik karena adanya sumbatan pembuluh darah oleh tromboembolik yang mengakibatkan daerah di bawah sumbatan tersebut mengalama iskemik. Sedangkan stroke hemoragik terjadi akibat adanya mikroaneurisme yang pecah. ${ }^{6}$

Faktor yang dapat menimbulkan stroke terdiri dari faktor yang dapat dimodifikasi dan yang tidak dapat dimodifikasi. Faktor yang tidak dapat dimodifikasi terdiri dari usia dan jenis kelamin, sedangkan faktor yang dapat dimodifikasi antara lain hipertensi, diabetes melitus, profil lipid, konsumsi alkohol, dan merokok. ${ }^{7,8}$

Hipertensi memegang peranan penting pada patogenesis atherosklerosis pembuluh darah besar yang selanjutnya akan menyebabkan stroke iskemik oleh karena oklusi trombotik arteri, emboli arteri ke arteri atau kombinasi keduanya. ${ }^{9}$

Diabetes melitus mampu menebalkan dinding pembuluh darah otak yang berukuran besar. Menebalnya dinding pembuluh darah otak akan menyempitkan diameter pembuluh darah tadi dan penyempitan tersebut kemudian akan mengganggu kelancaran aliran darah ke otak, yang pada akhirnya akan menyebabkan infark sel-sel otak. ${ }^{10}$

Tabel 1. Klasifikasi tekanan darah menurut JNC VII

\begin{tabular}{|c|c|c|}
\hline Kategori & $\begin{array}{c}\text { Sistolik } \\
(\mathrm{mmHg})\end{array}$ & $\begin{array}{c}\text { Diastolik } \\
\text { (mmHg) }\end{array}$ \\
\hline Normal & $<120$ & $<80$ \\
\hline Prehipertensi & 120-139 & $80-89$ \\
\hline $\begin{array}{c}\text { Hipertensi } \\
\text { tingkat } 1\end{array}$ & $140-159$ & $90-99$ \\
\hline $\begin{array}{c}\text { Hipertensi } \\
\text { tingkat } 2\end{array}$ & $\geq 160$ & $\geq 100$ \\
\hline
\end{tabular}

Berdasarkan standards of medical care in Diabetes 2010, kriteria diagnosis dari diabetes melitus yaitu glukosa darah puasa $(\mathrm{GDP}) \geq 126 \mathrm{mg} / \mathrm{dl}(7,0 \mathrm{mmol} / \mathrm{L})$ puasa didefinisikan tidak ada asupan kalori selama minimal 8 jam, glukosa darah dua jam $\geq 200 \mathrm{mg} / \mathrm{dl}(11,1 \mathrm{mmol} / \mathrm{L})$ selama tes toleransi glukosa oral (OGTT) beban glukosa yang digunakan mengandung setara dengan $75 \mathrm{~g}$ glukosa anhidrat dilarutkan dalam air atau pasien dengan gejala klasik hiperglikemia/krisis hiperglikemik, glukosa darah sewaktu $(\mathrm{GDS}) \geq 200 \mathrm{mg} / \mathrm{dL}(11,1 \mathrm{mmol} / \mathrm{L}) .{ }^{11}$

Tabel 2. Perbandingan tingkat serum kolesterol total, kolesterol LDL, kolesterol HDL dan Trigliserida. Sumber: Brashers V, 2008

\begin{tabular}{cccc}
\hline & $\begin{array}{c}\text { Diharapkan } \\
\text { (mg/dL) }\end{array}$ & $\begin{array}{c}\text { Risiko } \\
\text { Batas } \\
\text { (mg/dL) }\end{array}$ & $\begin{array}{c}\text { Risiko } \\
\text { Tinggi } \\
\text { (mg/dL) }\end{array}$ \\
\hline $\begin{array}{c}\text { Kolesterol } \\
\text { Total } \\
\text { Kolesterol } \\
\text { LDL }\end{array}$ & $<200$ & $200-239$ & $\geq 240$ \\
$\begin{array}{c}\text { Kolesterol } \\
\text { HDL }\end{array}$ & $\geq 50$ & $35-49$ & $<35$ \\
\begin{tabular}{c} 
Trigliserida \\
\multicolumn{2}{cl}{ resiko kemungkinan }
\end{tabular} \\
\hline
\end{tabular}

Kadar kolesterol yang tinggi mempromosikan pembentukan plak di arteri yang memasok jantung dan otak. 
Rendahnya tingkat HDL dan tingginya tingkat LDL merupakan faktor risiko stroke. Peningkatan trigliserida juga dapat mempromosikan pembentukan plak dan menyebabkan stroke. ${ }^{12}$

\section{METODE PENELITIAN}

Metode yang digunakan bersifat deskriptif retrospektif yaitu dengan mengambil data sekunder penderita stroke iskemik tahun 2012-2013 di bagian rekam medik RSUP Prof. Dr. R. D. Kandou. Data yang di ambil meliputi usia, jenis kelamin, pendidikan terakhir, pekerjaan, tekanan darah, kadar gula darah, profil lipid, kadar elektrolit, riwayat merokok, dan riwayat mengkonsumsi alkohol.

\section{HASIL PENELITIAN DAN BAHASAN}

Dari hasil penelitian melalui pengumpulan data secara retrospektif pada penderita stroke iskemik yang di rawat inap di bagian saraf RSUP Prof. Dr. R.D. Kandou Manado tahun 2012-2013 di dapat jumlah pasien stroke iskemik sebanyak 253 pasien. Dari 253 pasien hanya 75 pasien yang masuk dalam kriteria inklusi.

\section{Faktor Risiko yang Tidak Dapat Diubah}

\section{Umur}

Distribusi umur pasien yang terbanyak berkisar antara 45-54 tahun yaitu sebanyak 27 pasien (36\%) (Tabel 3).

Tabel 3. Distribusi Pasien stroke iskemik menurut usia pada pasien rawat inap di Bagian Saraf RSUP Prof. R.D Kandou Manado Tahun $2012-2013$

\begin{tabular}{ccc}
\hline Umur & $\mathbf{N}$ & $\mathbf{\%}$ \\
\hline $24-34$ & 1 & 1,3 \\
$35-44$ & 6 & 8,0 \\
$45-54$ & 27 & 36,0 \\
$55-64$ & 19 & 25,3 \\
$65-74$ & 16 & 21,3 \\
$>75$ & 6 & 8,0 \\
\hline Jumlah & 75 & 100,0 \\
\hline
\end{tabular}

Umur merupakan faktor risiko stroke iskemik yang paling kuat. Dengan meningkatnya umur, maka meningkat pula insidens iskemik serebral tanpa memandang etnis dan jenis kelamin. Setelah usia 55 tahun, insidensi akan meningkat dua kali tiap dekade. ${ }^{13}$

\section{Jenis Kelamin}

Distribusi pasien yang terbanyak berdasarkan jenis kelamin adalah laki-laki yaitu sebanyak 39 pasien (52\%) (Tabel 4).

Tabel 4. Distribusi Pasien stroke iskemik menurut jenis kelamin pada pasien rawat inap di Bagian Saraf RSUP Prof. R.D Kandou Manado Tahun 2012 - 2013

\begin{tabular}{ccc}
\hline $\begin{array}{c}\text { Jenis } \\
\text { Kelamin }\end{array}$ & $\mathbf{N}$ & $\mathbf{\%}$ \\
\hline Laki-laki & 39 & 52,0 \\
Perempuan & 36 & 48,0 \\
\hline Jumlah & 75 & 100,0 \\
\hline
\end{tabular}

Pada penelitian ini pasien stroke iskemik lebih banyak ditemukan pada lakilaki dibandingkan perempuan. Hal ini disebabkan karena perempuan lebih terlindungi dari penyakit jantung dan stroke sampai umur pertengahan akibat hormon estrogen yang dimilikinya. Setelah menopause risiko perempuan sama dengan laki-laki untuk terkena serangan stroke dan penyakit jantung. Banyak wanita menopause di Kanada meninggal akibat serangan stroke dan penyakit jantung pada setiap tahunnya dibandingkan dengan penyakit kanker. ${ }^{14}$

\section{Faktor Risiko yang Dapat Diubah}

\section{Hipertensi}

Berdasarkan Tabel 5 dapat dilihat bahwa 74,70\% mempunyai faktor risiko hipertensi (hipertensi derajat 1 dan derajat 2) yaitu sebanyak 56 pasien.

Peningkatan tekanan darah pada stroke iskemik merupakan respon otak yang bertujuan untuk meningkatkan tekanan perfusi otak sehingga aliran darah akan meningkat. Diharapkan dengan respon tersebut kerusakan di area penumbra tidak bertambah berat. Akibatnya, penurunan tekanan darah yang terlalu cepat pada 
Patricia, Kembuan, Tumboimbela: Karakteristik penderita stroke...

stroke iskemik akut dapat memperluas infark dan perburukan neurologis. ${ }^{15}$

Tabel 5. Distribusi Pasien stroke iskemik menurut faktor risiko hipertensi pada pasien rawat inap di Bagian Saraf RSUP Prof. R.D Kandou Manado Tahun 2012 - 2013

\begin{tabular}{ccc}
\hline $\begin{array}{c}\text { Tekanan } \\
\text { Darah }\end{array}$ & $\mathbf{N}$ & $\mathbf{\%}$ \\
\hline Normal & 11 & 14.7 \\
Prehipertensi & 8 & 10.7 \\
Grade I & 32 & 42.7 \\
Grade II & 24 & 32.0 \\
\hline Jumlah & 75 & 100 \\
\hline
\end{tabular}

\section{Diabetes Melitus}

Berdasarkan Tabel 6 dapat dilihat bahwa pasien stroke terbanyak memiliki nilai kadar gula darah sewaktu normal yaitu $<200 \mathrm{mg} / \mathrm{dl}$ sebanyak 62 pasien (82,7\%).

Tabel 6. Distribusi Pasien stroke iskemik menurut faktor risiko gula darah yang meningkat pada pasien rawat inap di Bagian Saraf RSUP Prof.R.D Kandou Manado Tahun $2012-2013$

\begin{tabular}{ccc}
\hline $\begin{array}{c}\text { Kadar gula } \\
\text { darah }\end{array}$ & N & \% \\
\hline Normal & 62 & 82,7 \\
Meningkat & 13 & 17,3 \\
\hline Jumlah & 75 & 100,0 \\
\hline
\end{tabular}

Pasien dengan DM tipe 2 memiliki risiko besar menderita stroke. Tingkat keparahan stroke pada diabetes tergantung dengan sekelompok faktor yang disebut "metabolik sindrom”, dikarakteristikkan dengan adanya resistensi insulin, hiperinsulinemia, hiperglikemi, obesitas dan dislipidemia. Semua faktor tersebut akan meningkatkan kerusakan vaskular. ${ }^{16}$

\section{Profil Lipid}

Dari hasil penelitian di dapatkan bahwa pasien stroke iskemik yang memiliki kadar kolesterol total yang meningkat sebanyak 31 pasien (41,3\%) (Tabel 7).

Kadar kolesterol yang tinggi dapat mempromosikan pembentukan plak di arteri yang memasok jantung dan otak. ${ }^{12}$

Tabel 7. Distribusi Pasien stroke iskemik menurut kolesterol total yang meningkat pada pasien rawat inap di Bagian Saraf RSUP Prof.R.D Kandou Manado Tahun 2012 - 2013

\begin{tabular}{ccc}
\hline $\begin{array}{c}\text { Kadar kolesterol } \\
\text { total }\end{array}$ & $\mathbf{N}$ & $\mathbf{\%}$ \\
\hline Normal & 44 & 58,7 \\
Meningkat & 31 & 41,3 \\
\hline Jumlah & 75 & 100,0 \\
\hline
\end{tabular}

Peningkatan kadar kolesterol LDL ditemukan sebanyak 26 pasien (34,7\%) (Tabel 8).

LDL membawa kolesterol dari hati ke sel-sel. Jika kadarnya tinggi akan mengakibatkan terjadinya penumpukan kolesterol di dinding pembuluh darah dan memicu terjadinya pengerasan dinding pembuluh darah yang berujung pada atherosklerosis. ${ }^{17}$

Tabel 8. Distribusi Pasien stroke iskemik menurut LDL yang meningkat pada pasien rawat inap di Bagian Saraf RSUP Prof.R.D Kandou Manado Tahun 2012 - 2013

\begin{tabular}{ccc}
\hline Kadar LDL & $\mathbf{N}$ & $\mathbf{\%}$ \\
\hline Normal & 49 & 65,3 \\
Meningkat & 26 & 34,7 \\
\hline Jumlah & 75 & 100,0 \\
\hline
\end{tabular}

Pada penelitian ini ditemukan penurunan kadar kolesterol HDL sebanyak 45 pasien (60\%) (Tabel 9)

Tabel 9. Distribusi Pasien stroke iskemik menurut HDL yang menurun pada pasien rawat inap di Bagian Saraf RSUP Prof. R.D Kandou Manado Tahun 2012 - 2013

\begin{tabular}{ccc}
\hline Kadar HDL & N & \% \\
\hline Normal & 30 & 40 \\
Menurun & 45 & 60 \\
\hline Jumlah & 75 & 100,0 \\
\hline
\end{tabular}

HDL bekerja untuk membawa kolesterol dari pembuluh darah arteri dan mengembalikan ke hati untuk dibuang. Oleh karena itu, HDL yang rendah dapat 
meningkatkan risiko untuk terkena stroke. ${ }^{18}$ Peningkatan kadar trigliserida ditemukan sebanyak 16 pasien (21,3\%) (Tabel 10$)$.

Tabel 10. Distribusi Pasien stroke iskemik menurut trigliserida yang meningkat pada pasien rawat inap di Bagian Saraf RSUP Prof.R.D Kandou Manado Tahun 2012 - 2013

\begin{tabular}{ccc}
\hline $\begin{array}{c}\text { Kadar } \\
\text { trigliserida }\end{array}$ & $\mathbf{N}$ & $\mathbf{\%}$ \\
\hline Normal & 59 & 78,7 \\
Meningkat & 16 & 21,3 \\
\hline Jumlah & 75 & 100,0 \\
\hline
\end{tabular}

\section{Alkohol}

Pasien stroke iskemik yang memiliki riwayat mengkonsumi alkohol yaitu sebanyak 21 pasien (28\%) (Tabel 11). Hasil ini tidak sesuai dengan teori yang mengatakan bahwa risiko stroke meningkat pada peminum berat dan sedang, tetapi bersifat protektif pada peminum ringan. ${ }^{19}$

Tabel 11. Distribusi Pasien stroke iskemik menurut faktor risiko konsumsi alkohol pada pasien rawat inap di Bagian Saraf RSUP Prof. R.D Kandou Manado Tahun 2012 - 2013

\begin{tabular}{ccc}
\hline $\begin{array}{c}\text { Penggunaan } \\
\text { Alkohol }\end{array}$ & N & $\mathbf{\%}$ \\
\hline Ya & 21 & 28 \\
Tidak & 54 & 72 \\
\hline Jumlah & 75 & 100,0 \\
\hline
\end{tabular}

\section{Merokok}

Penderita stroke iskemik dengan riwayat merokok yaitu sebanyak 33 pasien (44\%) (Tabel 12). Merokok meningkatkan risiko terjadinya stroke hampir dua kali lipat, dan perokok pasif terkena stroke 1,2 kali lebih besar.

Tabel 12. Distribusi Pasien stroke iskemik menurut faktor risiko merokok pada pasien rawat inap di Bagian Saraf RSUP Prof. R.D Kandou Manado Tahun 2012 - 2013

\begin{tabular}{ccc}
\hline Merokok & $\mathbf{N}$ & $\mathbf{\%}$ \\
\hline Ya & 33 & 44 \\
Tidak & 42 & 56 \\
\hline Jumlah & 75 & 100,0 \\
\hline
\end{tabular}

Nikotin dan karbondioksida yang ada pada rokok menyebabkan kelainan pada dinding pembuluh darah, disamping itu juga mempengaruhi komposisi darah sehingga mempermudah terjadinya proses gumpalan darah. $^{20}$

\section{Gangguan Elektrolit Sebagai Faktor Lain}

Pasien stroke iskemik yang memiliki kadar natrium rendah (hiponatrium) sebanyak 7 pasien $(9,3 \%)$ dan hipernatrium sebanyak 2 pasien (2,7\%) (Tabel 13).

Tabel 13. Distribusi Pasien stroke iskemik menurut kadar natrium pada pasien rawat inap di Bagian Saraf RSUP Prof.R.D Kandou Manado Tahun 2012 - 2013

\begin{tabular}{ccc}
\hline Natrium & $\mathbf{N}$ & $\mathbf{\%}$ \\
\hline Normal & 66 & 88 \\
Hiponatremia & 7 & 9.3 \\
Hipernatremia & 2 & 2.7 \\
\hline Jumlah & 75 & 100.0 \\
\hline
\end{tabular}

Pasien stroke iskemik yang memiliki kadar kalium rendah (hipokalium) sebanyak 9 pasien (12\%) dan hiperkalium 3 pasien (4\%). Totalnya 16\% pasien stroke iskemik yang memiliki ketidakseimbangan kalium (Tabel 14).

Tabel 14. Distribusi Pasien stroke iskemik menurut menurut kadar kalium pada pasien rawat inap di Bagian Saraf RSUP Prof.R.D Kandou Manado Tahun 2012 - 2013

\begin{tabular}{ccc}
\hline Kalium & $\mathbf{N}$ & $\mathbf{\%}$ \\
\hline Normal & 63 & 84 \\
Hipokalemia & 9 & 12 \\
Hiperkalemia & 3 & 4 \\
\hline Jumlah & 75 & 100,0 \\
\hline
\end{tabular}

Pasien stroke iskemik yang memiliki kadar klorida rendah (hipokloridemia) sebanyak 6 pasien (8\%) dan hiperkloridemia sebanyak 8 pasien $(10,7 \%)$ (Tabel 15). Hal ini sesuai dengan penelitian yang dilakukan Kembuan di RSUP Prof. R.D. Kandou Manado tahun 2014 yang menyatakan proporsi pasien stroke dengan hiponatremia $7,1 \%$, hipernatremia $1,2 \%$, 
Patricia, Kembuan, Tumboimbela: Karakteristik penderita stroke...

hipokalemia 37,6\%, hiperkalemia 2,4\%. ${ }^{21}$

Tabel 15. Distribusi Pasien stroke iskemik menurut kadar klorida pada pasien rawat inap di Bagian Saraf RSUP Prof.R.D Kandou Manado Tahun 2012 - 2013

\begin{tabular}{ccc}
\hline Klorida & $\mathbf{N}$ & $\mathbf{\%}$ \\
\hline Normal & 61 & 81,3 \\
Hipokloridemia & 6 & 8 \\
Hiperkloridemia & 8 & 10,7 \\
\hline Jumlah & 75 & 100,0 \\
\hline
\end{tabular}

\section{Status Sosial Ekonomi}

\section{Pendidikan Terakhir}

Distribusi pasien yang terbanyak berdasarkan pendidikan terakhir adalah SMA yaitu sebanyak 39 pasien (52\%) (Tabel 16).

Tingkat pendidikan sebagai faktor sosial ekonomi memang tidak berkaitan langsung dengan kejadian stroke. Akan tetapi, tingkat pendidikan seseorang menentukan sikap orang tersebut terhadap perilaku sehat. Oleh karena itu, seseorang dengan tingkat pendidikan yang lebih tinggi diharapkan mampu memahami informasi kesehatan dan mengaplikasikannya dalam kehidupan sehari-hari. ${ }^{22}$

Tabel 16. Distribusi Pasien stroke iskemik menurut pendidikan terakhir pada pasien rawat inap di Bagian Saraf RSUP Prof. R.D Kandou Manado Tahun 2012 - 2013

\begin{tabular}{ccc}
\hline $\begin{array}{c}\text { Pendidikan } \\
\text { Terakhir }\end{array}$ & N & \% \\
\hline Tidak Sekolah & 2 & 2,7 \\
SD & 13 & 17,3 \\
SMP & 11 & 14,7 \\
SMA & 39 & 52,0 \\
Sarjana & 10 & 13,3 \\
\hline Jumlah & 75 &, 00.0 \\
\hline
\end{tabular}

\section{Pekerjaan}

Distribusi pasien yang terbanyak berdasarkan pekerjaan adalah Ibu Rumah Tangga yaitu sebanyak 30 pasien (40\%) (Tabel 17).
Tabel 17. Distribusi Pasien stroke iskemik menurut pekerjaan pada pasien rawat inap di Bagian Saraf RSUP Prof.R.D Kandou Manado Tahun 2012 - 2013

\begin{tabular}{ccc}
\hline Pekerjaan & N & $\mathbf{\%}$ \\
\hline Pegawai Negeri & 11 & 14,7 \\
Pegawai Swasta & 7 & 9,3 \\
Pensiunan & 5 & 6,7 \\
IRT & 30 & 40,0 \\
Tidak Bekerja & 2 & 2,7 \\
Lain-lain & 20 & 26,7 \\
\hline Jumlah & 75 & 100 \\
\hline
\end{tabular}

\section{SIMPULAN}

Berdasarkan hasil penilitian ini disimpulkan bahwa faktor risiko terbanyak yang ditemui ialah hipertensi.

\section{SARAN}

1. Kepada pihak RSUP Prof. R.D. Kandou Manado agar lebih melengkapi sistem pencatatatan di bagian rekam medik sehingga mempermudah pengambilan data bagi pihak yang membutuhkannnya, baik bagi kepentingan penderita, klinisi maupun penelitian.

2. Untuk peneliti selanjutnya agar dapat menanyakan langsung kepada pasien, tidak hanya melalui rekam medik saja, karena keterbatasan informasi yang terdapat pada rekam medik. Agar juga dapat lebih memperluas cakupan penelitiannya khususnya dalam jumlah sampel dan lokasi penelitian sehingga dapat lebih bermanfaat dalam perkembangan ilmu pengetahuan di bidang kedokteran dan kesehatan.

3. Kepada pembaca, perlunya kesaran terhadap gaya hidup sehari-hari yang lebih sehat, terutama bagi mereka yang memiliki beberapa faktor risiko, untuk menghindari konsumsi makanan tinggi kolesterol dan lemak menghentikan kebiasaan merokok dan alkohol, olahraga yang teratur, dan meningkatkan konsumsi buah-buahan dan sayuran. 
DAFTAR PUSTAKA

1. International Task Force for Prevention of Coronary Heart Disease Stroke. Definition of Stroke established by WHO in 1980. http://www.chdtaskforce.de/pdf/sk_stroke_02.pdf (diakses 7 September 2014)

2. WHO/SEARO. Surveillance of major noncommunicable disease in South East Asia region. Report of an intercountry consultation. Geneva:2005

3. Stroke Facts. Center for Disease Control and Prevention. http://www.cdc.gov/stroke/facts.htm (diakses 7 September 2014)

4. Stroke Statistics.pdf - stroke Association. http://www.stroke.org.uk/sites/default /files/stroke\%20statistics.pdf (diakses 7 September 2014)

5. Laporan RISKESDAS 2013. Riset Kesehatan Dasar. Badan Litbangkes.

6. Sacco R, Kosner S, Broderick J, Caplan L, Cannor, Culebras A, et al. An Updated Definition of Stroke for the 21st Century. American Heart Association/American Stroke Association. July 2013; 44: 2064-89

7. Feigin V. Stroke Panduan Bergambar Tentang Pencegahan dan Pemulihan Stroke. Jakarta: PT.Bhuana Ilmu Populer; 2006

8. Stroke-Risk Factors for Stroke. http://nihseniorhealth.gov/stroke/riskf actor/01.html

9. Susilo H. The Powerful Blood Pressure Reduction in Hypertensive Stroke Patients With Single Pill Combination of Valsartan and Amlodipine. Yogyakarta: Panitia Konas Perdossi. Pustaka Cendekia Press. Yogyakarta; 2011

10.Harsono (editor). Buku Ajar Neurologi Klinis. Yogyakarta: Gadjah Mada University Press; 2011:59-109

11.American Diabetes Association. Standards of medical care in diabetes 2014.
Diabetes Care. 2014;37: p.5-13

12.Caplan LR. Stroke. Chapter 4 How Can Stroke Be Prevented. American Academy of Neurology. New York : 2006. p.39-56

13.Ardelt AA. Acute Ischemic Stroke. In: Harrigan M.R and Deveikis, J.P, ed. Handbook of Cerebrovascular Disease and Neurointerventional Technique. Humana Press. New York: 2009. p.571-605

14. Heart and Stroke Foundation (2010). A Perfect Storm of Heart Disease Looming On Our Horizon.

15.Mardjono M. Mekanisme Gangguan Vaskular Susunan Saraf. Neurologi Klinis Dasar ed.11. Jakarta: Dian Rakyat; 2006. p.270-93

16.Asfandiyarova R, Kolcheva N, Ryazantsev I, Ryazantsev V. Risk Factors for Stroke in Type 2 Diabetes Mellitus; 2006

17.Simon RP, Greenberg DA, Aminott MJ. Clinical Neurology edisi Internasional. USA: McGrawHill; 2009

18.Stroke Association. Converging Risk Factors. www.strokeassociation.org

19.Sacco RL, Bernadette BA. Stroke Risk Factors; Identification and Modification In Stroke Therapy. 2nd ed. Boston. Butterworth-Heinemann. p.1-17

20.Madiyono B, Suherman SK. Pencegahan Stroke dan Serangan Jantung Pada Usia Muda. Jakarta: Balai Penerbit FKUI; 2003. p.3-11

21.Kembuan M, Sekeon S. Electrolyte Disturbance Among Acute Stroke Patients In Manado, Indonesia. Global Journal of Medicine and Public Health Vol.3 No.1; 2014.

22.Notoatmodjo S. Promosi Kesehatan dan Ilmu Perilaku. Jakarta: Rineka Cipta; 2007. 